\title{
The view of nurses about educational practices targeted at people with a stoma
}

\author{
A visão dos enfermeiros sobre as práticas educativas direcionadas as pessoas estomizadas
} La visión de los enfermeros sobre las prácticas educativas dirigidas estomizadas personas

\author{
Vanessa Cristina Maurício \\ Norma Valéria Dantas de Oliveira Souza ${ }^{1}$ \\ Carolina Cabral Pereira da Costa $^{1}$ \\ Midian Oliveira Dias ${ }^{1}$
}

1. Universidade do Estado do Rio de Janeiro.

Rio de Janeiro, RJ, Brazil.
Corresponding author:

Midian Oliveira Dias.

E-mail: dias.midian@gmail.com

Submitted on 03/04/2017.

Accepted on 08/06/2017.

DOI: 10.1590/2177-9465-EAN-2017-0003

\section{Abstract}

Objective: To analyze the point of view of nurses in respect to educational activities aimed at social inclusion of people with ostomies. Method: A qualitative and exploratory, interpretive and critical study based on a dialectical perspective was carried out with six nurses in a municipal rehabilitation center in Rio de Janeiro. The triangulation method was used with individual interviews, participant observation and analysis of documents. Data was analyzed using a historical and dialectical approach. Results: The preparation of people with a stoma in relation to achieving autonomy and independence through teaching self-care was considered important by the nurses; this aspect was highlighted as the most important of all actions performed in the educational process. Conclusions: The nurses had a humanized practice with the educational strategies used by these professionals aiming at making the educational process more dynamic, focused on practical nursing and directed toward real customer needs.

Keywords: Surgical Stomas; Nursing; Health education.

\section{Resumo}

Objetivo: Analisar o ponto de vista dos enfermeiros sobre as ações educativas realizadas com as pessoas com estomia, visando à inclusão social. Método: Pesquisa qualitativa e exploratória, interpretativa e crítica, apoiada na perspectiva dialética, realizada em um Centro Municipal de Reabilitação, do Rio de Janeiro, com seis enfermeiros. Utilizou-se a triangulação do método por meio da entrevista individual, da observação participante e da análise documental. Analisaram-se as informações a partir da abordagem histórico-dialética. Resultados: Os enfermeiros consideraram importante o preparo das pessoas com estomia para o alcance da autonomia e independência através do ensino do autocuidado, e destacaram esse aspecto como o mais relevante entre todas as ações realizadas no processo educativo. Conclusões: Os enfermeiros apresentavam uma prática humanizada e as estratégias educativas realizadas por estes profissionais objetivavam tornar o processo educativo mais dinâmico, voltado para a prática e direcionado às reais necessidades da clientela.

Palavras-chave: Estomas cirúrgicos; Enfermagem; Educação em saúde.

\section{Resumen}

Objetivo: Analizar los puntos de vista de las enfermeras en las actividades educativas con personas con ostomía, dirigidos a la inclusión social. Método: Cualitativa y exploratoria, interpretativo y crítico, basado en la perspectiva dialéctica, que se celebró en un Centro de Rehabilitación Municipal, en Río de Janeiro, con seis enfermeras. Se utilizó el método de triangulación a través de entrevistas individuales, observación participante y análisis de documentos. Analizar la información desde el enfoque histórico y dialéctico. Resultados: Las enfermeras consideran importante la preparación de las personas con estoma para el logro de la autonomía y la independencia a través de la educación de autocuidado, y pusieron de relieve este aspecto como la más importante de todas las acciones realizadas en el proceso educativo. Conclusiones: Las enfermeras tuvieron una práctica humanizada y estrategias educativas utilizadas por estos profesionales destinadas a convertirse en el proceso educativo más dinámico, destinadas a la práctica y dirigidos a las necesidades reales de los clientes.

Palabras clave: Estomas quirúrgica; Enfermería; Educación para la salud. 


\section{INTRODUCTION}

The present article is part of the doctoral thesis entitled: "The educational process developed by nurses focused on labor inclusion of people with a stoma",, defended in December of 2015 at the State University of Rio de Janeiro. The purpose of this paper is to analyze the nurses' point of view about educational practices targeting social inclusion of people with a stoma.

With the increase in the number of people with a stoma in Brazil, the importance of nurses in the counselling process is indispensable, as nurses offer psychosocial support and help to improve the quality of life of these clients.

The most common pathologies that lead to the establishment of ostomies in patients are colon and rectum cancers that, according to Brazilian National Cancer Institute (INCA) estimates for 2014 and 2015, are the fourth most prevalent types of neoplasms in men and the third most common in women. Other reasons include inflammatory bowel diseases such as ulcerative colitis and Crohn's disease, and other types of malignancies such as bladder, uterus and gynecological cancer. ${ }^{2}$

In this context, nursing consultations are important and should be periodic, encompassing several aspects of rehabilitation, including counseling about self-care, which is defined as a regulatory function that allows individuals to perform activities that aim at the preservation of life, health and wellbeing. ${ }^{3}$

Thus, the educational process cannot be fragmented, as individuals, imbued with multidimensionality, need holistic and integral care. ${ }^{4}$ Thus, the orientation aims to help the client overcome difficulties of daily life and achieve the desired social inclusion based on the changes in their lives resulting from an ostomy. ${ }^{5,6}$

Health education carried out by nurses is fundamental in the rehabilitation process, since it is aimed at assisting the adaptation of these people to the new health condition in order for them to achieve greater independence, autonomy and social inclusion. ${ }^{7}$

This study is justified, since after searching national and international online and printed databases, it was verified that the studies related to this theme need further investigation. Another fact that substantiates the choice of this issue is the increase in the number of people with a stoma in Brazil and in the world. A total of 15,070 new cases of colon and rectum cancer are predicted in men and 17,530 in women within the Brazilian context. ${ }^{2}$

In view of this, the following guiding question was designed: What are the educational actions developed by nurses that promote social inclusion of people with a stoma?

The following objective was elaborated in order to answer this guiding question and comprehend the subject of this study: to analyze, from the point of view of the nurses, educative actions carried out with people with a stoma targeting social inclusion.

\section{LITERATURE REVIEW}

The term "ostomy" means to surgically create an opening into a hollow organ such as a portion of the digestive, respiratory or urinary tract, resulting in a communication with the external environment, when there is a need to temporarily or permanently divert the normal traffic of urine, excrement or air and/or food. ${ }^{8}$

To have an ostomy, even temporarily, means there will be many changes in the individual's life affecting biopsychosocial, cultural and spiritual aspects, mainly related to the loss of sphincter control.5,9

The presence of an ostomy generates two distinct feelings in people, a prolongation of life and an improvement in its quality or great suffering mainly due to the changes necessary in day-to-day activities. Therefore, the professional that serves this clientele must have knowledge about this dialectic of feelings and be properly trained to act, as it is constantly mentioned by clients. ${ }^{10,11}$

Providing guidance to people with a stoma in relation to self-care essential starts in the preoperative period and continues when the client has the stoma. Therefore, specialized or generalist nurses should adequately advise clients on the correct use of collecting and accessory equipment, so as to avoid problems with the skin, to reduce physical discomfort and assist in their social reintegration. ${ }^{4}$

Education and health are related; both represent spaces of production and application of knowledge intended for the development of individuals. In this sense, health professionals, specifically nurses, use a permanent cycle of teaching and learning, ${ }^{12}$ as the educational process is considered a fundamental instrument for quality care.

It is believed that it is possible to critically teach and learn in nursing within stomal therapy; however, it is essential that nurses respect the socially and historically constructed knowledge of the client. ${ }^{13}$

\section{METHODS}

This study is characterized as qualitative and exploratory of an interpretative and critical nature supported by the dialectical perspective.

It is emphasized that the interpretive character leads the researcher to construct an intersubjectivity, that is, an interaction with research participants in order to understand their actions and attitudes. The critical character of studies allows a logical reflection of data found in the field, seeking to understand the dialectic present in this setting and in the studied relationships. ${ }^{14}$

In the research, the interpretive character and critical character were employed at all stages of data collection; the data were not just described but were also subjected to reflection during data collection itself, correlating it to the various factors present in the individual's reality (Historical, social, economic, political), which later favored data analysis. 
The dialectical perspective represents a way of understanding reality as contradictory and constantly changing. Dialectics comprises phenomena in their totality, taking into account the historical, economic, social, and political aspects that permeate opinions. ${ }^{15}$ In relation to the educational process of people with a stoma, the dialectic aims to understand how opinions develop in their totality, considering the contradictions that pervade them, correlating them to the historical, economic, social and political aspects found in the relationships between the actors of the research.

The proximity of the object of the study to the proposed method was identified, because in order to verify nurses' points of view about educational practices of those with a stoma, we must consider the historicity and socioeconomic contexts in which the social actors are inserted.

The site of this research was a municipal rehabilitation center located in Rio de Janeiro, where the Care Program for People with a stoma is developed.

The study participants were six nurses who worked in this rehabilitation center and who met the following inclusion criteria:

a) To be part of the functional framework of the municipal center as a government employee or under a work contract;

b) To be a nurse who acts or has acted in the Care Program for People with a Stoma;

c) To be a nurse who participates in or has already participated in the educational process of the people with a stoma attended by the institution;

d) To be a professional who has had at least two years of experience after graduating in the nursing undergraduate course;

e) To be a nurse who has worked with people with a stoma for more than six months with experience in the educational process of the client;

f) To be a nurse who was working during the data collection period of the research.

The exclusion criteria were:

a) To be a nurse of the rehabilitation center that does not act and has never acted in the educative process of people with a stoma;

b) To be a nurse who was on vacation or on leave at the time of data collection;

c) To be a nurse with less than two years of professional experience;

d) To be a newly admitted nurse in the program who has had less than six months of experience in the educational process of people with a stoma.
The nursing staff of the municipal health center directly connected to the program comprised of seven nurses. Of these, one was the coordinator, but had already cared for people with a stoma and six nurses worked in nursing consultations. However, one nurse refused to participate in the study for personal reasons.

We chose to work with the triangulation method for data collection using participant observation, a semi-structured individual interview and a study of documents.

The observation period lasted for three months, totaling 120 hours. The same occurred for nursing consultations, focusing on the description of the educational process performed by the nurses for clients with a stoma with the observations being recorded in a field diary that contained information on the descriptive and reflective content, which provided support for deeper discussions.

Questions regarding the educational process of the person with a stoma were included in the script of the interview of this research thus allowing reflective notes about the issues that arose during the discussion.

The study of documents was based on an analysis of the nurses' notes in the records of clients with a stoma that were attended in nursing consultations between December 2014 and March 2015. The items evaluated in the medical records were the records with nursing notes in relation to care and the guidance provided to people with a stoma during the educational process.

The three techniques proved to be pertinent to the research because they complement each other, providing information for the analysis of the data and detecting contradictions found in the nursing practice, besides being adequate for the theoretical methodological reference of the study.

This study was submitted for evaluation and approval of the Research Ethics Committee of the study institution (\#843.566 and \#902.611). The nurses and people with a stoma were given a free and informed consent form guaranteeing them freedom to participate voluntarily in the study without fear of any percussions on refusal in respect to health care, according to Resolution 466/2012 of the Brazilian National Health Council. ${ }^{16}$

In order to maintain confidentiality of the study participants, we chose to represent the nurses by the letter $\mathrm{N}$ followed by Arabic numerals in the order in which the interviews took place (from 1 to 6 ).

We opted to work with the historical-dialectic approach in the treatment of information as it generated a closer interpretation of reality. The interviews were transcribed, coded and categorized. The following category was reached after the application of the method: Visions and idealizations of the nurses about the educational process.

\section{RESULTS AND DISCUSSION}

The nurses reported in the interviews that guidance about the handling and changing of the collection equipment was an essential part of the educational process during nursing consultations about the person's health condition: 
The most important thing is to know how to handle the equipment he is using and to know what he has, how it was made. In addition, it is important to demonstrate how everything works (N2).

It is extremely important to guide the person with a stoma about what it is and to teach how to empty and change the collection bag ( $N$ 5).

Thus, it is perceived that counseling the client about the state of his health, about the meaning of an ostomy, as well as presenting the collecting equipment, demonstrating how to make the exchanges and handling it, is essential to adapt to his new health condition.

However, such guidance should not be given alone and should not be focused only on skin care and equipment use, since the needs of people with a stoma encompass psychosocial dimensions as well as physical alterations. ${ }^{17,18}$

This analysis was corroborated by participant observation during the nursing consultations and in the analysis of the medical records of people with a stoma, where the most common orientation was focused on the physical aspects. Thus, the psychosocial character of counseling, when offered, was not developed to the necessary depth. This fact pointed to a gap in the educational process of these clients, since the rehabilitation process advocates holistic guidance, aiming at their return to activities of daily living.

The majority of nurses considered it important to prepare people with a stoma, through the teaching of self-care, to achieve autonomy and independence and highlighted this aspect as the most relevant among all actions carried out in the educational process:

Self-care teaching will help people with a stoma to perform their activities and maintain their autonomy, this is our goal as a professional (N2).

I think the most important thing is the incentive to autonomy, to independence through teaching self-care. Because he will only have independence and autonomy when he has mastered his own care (N 6).

The teaching of self-care is extremely important in the process of rehabilitation of the person with a stoma, since the individual becomes a participatory agent in their care and adapts more easily to the new situation, developing activities that aim to promote their quality of life, Recover their health or overcome diseases. ${ }^{18,19}$

On the other hand, some nurses emphasized that all the guidance developed in the nursing consultations were equally important in the educational process of people with a stoma, but did not state what these procedures were or give examples:
I do not have an orientation that I can say that this is not important, because I think all orientations are important for the good adaptation of people with a stoma, for their independence (N 1).

I consider the importance of everything that I transmit to the people with a stoma; they need to leave here with all their doubts clarified to be able to carry out the care at home (N2).

The person with a stoma needs overall guidance on their new life condition, covering the biopsychosocial aspects, ranging from the physical changes centered on the loss of sphincter control and dependence on the collection equipment, to the incentive to overcome emotional difficulties in search of social inclusion. ${ }^{20,21}$

In order for these individuals to achieve a better quality of life, the professionals involved in the health-disease process, in particular the nurses, should guide clients in relation to four dimensions: a) physical well-being and functional status, b) psychological well-being, (c) social well-being, and (d) spiritual well-being. All these dimensions should also be equally addressed in the educational process, as they are closely related and are important in the rehabilitation process of clients. ${ }^{22}$

However, it should be pointed out that participant N1, who referred to an educational process that did not place one dimension of care over another, later in her interview, mentioned that her educational actions were centered on guidance that addressed the physical recovery of people with a stoma:

I develop my guidance for the self-care of people with a stoma eminently focused on physical issues. Thus, I tell you that this part, of social inclusion, I almost do not approach and do not privilege in my educational process (N1).

Thus, it was considered that this nurse approached only questions directed to the physical recovery of the person with a stoma in her consultations. However, in the participative observation of consultations, it was seen that although the focus of care was actually physical rehabilitation, there was also counseling on the return to leisure activities, as well as referral of clients to a nutritionist and social worker, which demonstrated a certain contradiction between discourse and practice.

The importance given by some nurses to the physiological orientations represents professional qualifications with a strong influence of the biomedical model, in which the individual is evaluated and taken care of in a fragmented way. In this model, the care of the patient with a stoma is centered on the evaluation and on measures directed to the stoma, as well as in counseling on the use of the collection equipment and skin care. In this way, 
the educational process occurs in a fragmented way, without meeting the needs of the individual as an indivisible whole. In this perspective, the guidance to overcome the psychosocial difficulties are reduced and not privileged.

Participating nurses added other insights about the educational process of people with a stoma: a) the educational process depends on an initial assessment of the client's prior knowledge; b) the first consultation should be brief, as clients do not assimilate large amounts of counseling; c) some clients first need a psychological approach with active and empathic listening; d) there is a presupposition about the educational process, which is characterized as dynamic and transformative, that is, nurses also learn from clients and become multipliers of this new knowledge; e) guidance provided by nurses at the rehabilitation center is of high quality.

In this sense, we have selected some lines that exemplify this analysis:

It is important to evaluate the patient, since we have those who receive guidance and do not absorb it, those who do not receive guidance, and we even have the curious who come here changing the bag, even without simple guidance. Thus, the nurse has to evaluate this whole context to be able to create a good educational process (N2).

The educational process will depend exclusively on the initial evaluation that is done with the client, of what he already knows and carried out in relation to care with the stoma. Some already have knowledge, but others come with little guidance (N 3).

I always start my appointment by asking what the person with a stoma knows. It is important to know their knowledge to carry out an educational process focused on their needs (N 6).

The evaluation of the clients' knowledge about their ability of self-care and to develop activities of daily life should occur continuously, since it is from this systematic evaluation that the nurse manages to elaborate a care plan adapted to the real needs of the client, besides gauging the level of understanding in relation to the guidance provided. ${ }^{19,23}$ In addition, it was observed that people with a stoma, when guided by hospital nurses in the pre-and post-operative periods, arrive at the rehabilitation center with less difficulties and tend to adapt better to the condition of having a stoma.

The continuous attendance of the person with a stoma in nursing consultations helps them adapt to the existence of the stoma; in addition, they begin to understand better of the changes that have occurred in their lives, thus contributing to the rehabilitation process and social inclusion. Furthermore, it is found that this helps create a closer relationship between the educator and the client, thereby favoring the educational process. ${ }^{22}$

Two nurses provided their insight that people with a stoma fail to grasp most of the orientations of the first consultation, reinforcing the need for a more synthetic educational process at this stage. The priority would be the care of the stoma and the skin, as well as the handling of the collecting equipment.

Often, I realize that it's no use giving many orientations at the first consultation because everything is new to them, and if you overwhelm the person with clarification and guidance, he will not be able to take in everything. So it is better to give little by little, counseling first how he should change the equipment and take care of his skin. I even see that the second time he comes and asks about the same things again (N 3).

I know that much of what I advise here in the first consultation will not be absorbed, often he is worried if the bag will burst and leak in the street, how he will get home, anyway [...] he is still adapting. Although I speak a lot in this first moment, the ideal is that he will receive guidance gradually (N 6).

The client in the first consultation is frightened by the radical changes in his life, namely, incontinence, the need to use equipment to store body effluent, the changes in the self-image, the need to change clothing, among other changes that are so paradigmatic that surely hinder the understanding of knowledge at first. Thus, it is mandatory for nurses to develop the educational process gradually and according to the questions of the client and family without forgetting guidance that is vital for the proper functioning of the stoma and the client's life. Thus, this conduct depends on a good evaluation and an empathic and problematizing approach. ${ }^{24}$

Another factor that should be analyzed is that a significant number of clients do not return to nursing appointments on a regular basis. One aspect that can interfere with this frequency is the fact that a large part of the population treated in this unit is economically deprived, and travel by public transport requires money, which clients do not always have.

Otherwise, consultations are on demand; during the participant observations strategies were not identified that stimulated the return of the client for anything other than to receive the collecting and accessory equipment, or related to a major complication such as peristaltic dermatitis, a hernia, granuloma or stenosis of the stoma. This situation could also be another reason that clients do not return for consultations.

Thus, it is up to nurses to develop attractive and technically adequate conduct during consultations to ensure client return, since guidance must be provided in a systematic and continuous manner, as the client's biopsychosocial conditions are dynamic and require constant reevaluations. ${ }^{24,25}$ 
Adding data to this analysis, it was shown that people with a stoma needed more emotional support during the first consultation and that questions of a physiological nature were relegated to the background.

Some, we have to completely change the technique because of his need, his demand, is much more emotional than anything else. Therefore, we end up having to be a bit of a psychologist, and the focus of the consultation goes all the way to the self-help question (N 6).

This fact was identified during some consultations carried out with clients with a stoma who were entering the institution. They were extremely fragile with the change in their body image and fear of prejudice that they could suffer socially. The pressing concern with psychosocial issues is justified by the historical configuration of society, which values the beautiful and perfect body and excludes, stigmatizes and segregates those different from this. ${ }^{26}$

People with a stoma need continuous psychological support and professionals must understand that coping with the condition of the client with a stoma and their new needs are sources of stress, which can be positively harnessed if they are seen as opportunities to adopt new perspectives on life. Nurses, as actors involved in the educational process of people with a stoma, should include in their consultations guidance to try to minimize feelings of mourning and sadness, encouraging subjects to continue with their life plans. ${ }^{27}$

One nurse in this study stressed that the exchange of experiences between the educator and the person with a stoma is of utmost importance for the educational process noting that one constantly learns from the client.

The patient often gives you the solutions to certain problems and then you end up being a multiplier of these solutions to other clients and professionals who experience similar situations. You hear from one, and it may be that the other uses the same artifice and you end up reproducing it. So the exchange of knowledge and experience is paramount in the orientation process, since it allows better solutions to the problems of the client (N 6).

Although this point of view emerged in only one interview, it was considered extremely relevant, since it demarcated what the educational process should be, that is, an exchange of knowledge in which there are no subjects devoid of knowledge and there is always something to learn and to improve with the experiences of other people, even though the driver of the process is the educator.
Paulo Freire, in his proposal of critical education and dialogic methodology, emphasizes this construction and improvement of knowledge from the exchange of experiences between educator and pupil. The author highlights some advantages of this methodology: a) identification of the problems encountered in the reality experienced by the person; b) joint reflection on the problems encountered seeking alternatives to overcome them; c) proposition of practical interventions in reality to transform it; and d) socialization of knowledge. ${ }^{20,21}$ And this methodology and its advantages were perceived by nurse $\mathrm{N} 6$.

Compliance of people with stoma to self-care becomes, in the view of nurses, essential for them to be included in work activities, as the discourse shows:

I think self-care would help him in this process of inclusion at work and also the incentive, right! If the client is well adapted to the equipment, and knowing how to do everything right, he will be able to work more safely! (N3).

In this first moment of returning to work, I perceive that the most important thing would be to be in control of exchanging this equipment, isn't that so, developing his self-care, to feel more comfortable, adapted (N5).

Dominating self-care makes it possible for people with a stoma take care of their stoma and their skin properly, as well as safely perform the exchange of the collection equipment. The acquisition of this autonomy and independence generates a sense of security to live in society, because clients with a stoma will be able to use strategies when there is an accident of extravasation of feces or excessive gas production. ${ }^{18,28}$

\section{CONCLUSIONS AND IMPLICATIONS FOR PRACTICE}

The results of the study contemplated the objectives of the research, highlighting the importance of systematized educational activities performed by nurses for people with a stoma, promoting their social inclusion, as well as pointing out the need for the development of new studies in the area of stomal therapy.

In general, the educational actions of nursing carried out during the consultations were directed to the physiological dimension of these people and psychosocial aspects were not considered.

The educational actions considered most important by the nurses were directed to the teaching of self-care, mainly in relation to the care of the stoma and the handling of the collecting equipment. However, when nurses discussed care for people with a stoma, they mentioned the need to assist clients holistically, thus characterizing an important contradiction that leads to misunderstandings in the educational process of these people. 
The study showed that nurses have several points of view about the educational process for people with a stoma, in relation to the social inclusion of these individuals. Otherwise, it was found that only two nurses recognized the importance of psychosocial guidance for the success of rehabilitation and addressed them in their consultations, even though in an incipient manner.

In this sense, the need for a qualitative improvement in relation to the educational process of the nurses for people with a stoma is apparent, so that they develop psychosocial issues with these clients such as returning to work, questions about sexuality, sports, leisure, and clothing, among others.

Some strategies are suggested that could facilitate the educative process, but that were not in the institute such as: a) access to technological and audiovisual resources; B) an administrative assistant to carry out administrative tasks; C) an adapted bathroom; D) the formation of support groups; and e) disclosure about what it is like to be a person with a stoma.

Some of these suggestions certainly can and should be put into practice immediately, such as forming support groups, conducting research and projects, and developing and delivering educational folders. Others are goals for the medium and long term, as they depend on political, economic and social reformulation, such as changes in the training process, and on governmental and social actions.

Limitations of this research included the use of a single study site, besides the small number of nurses participating in the research and the incipient nursing records in the patients' medical records. At the time of data collection, it was observed that even with a small number of participants, the nurses had similar ideas and actions for the educational practices performed with clients with a stoma, which suggested a saturation of the collected data.

In addition, the study site, because it is a municipal referral center to care for clients with a stoma for the state of Rio de Janeiro, reflects similar conditions to other care units, characterizing the findings as valid and pertinent. In relation to the data from documents, its incipience was minimized by the participant observations and interviews, which complemented the findings of the study.

It is important to emphasize the need for complementary studies on this theme, since there is a lack of research on educational practices in respect to social inclusion aimed at people with a stoma. Likewise, it is expected that health professionals will be made aware of the importance of the efficient and comprehensive educational process in the care of these clients.

\section{REFERENCES}

1. Mauricio VC. Processo educativo desenvolvido por enfermeiros voltado para inclusão laboral de pessoas com estomia [Thesis]. Rio de Janeiro (RJ): Faculdade de Enfermagem, Universidade do Estado do Rio de Janeiro; 2015. 266 p.
2. Instituto Nacional de Câncer José Alencar Gomes da Silva (BR) Coordenação Geral de Ações Estratégicas. Coordenação de Prevenção e Vigilância. Estimativa 2014: incidência de câncer no Brasil. Rio de Janeiro: INCA; 2014. 122 p.

3. Galvão MTRLS, Janeiro JMSV. Self-care in nursing: self-management self-monitoring, and the management of symptoms as related concepts. Reme Rev Min Enferm [Internet]. 2013 Jan/Mar; [cited 2017 Apr 18]; 17(1):225-35. Available from: http://www.reme.org.br/artigo/ detalhes/593. DOI: 10.5935/1415-2762.20130019

4. Souza DC, Diniz SOS, Silva PS, Silva TCT, Santiago LC. Educação à distância: uma metodologia de ensino em expansão na enfermagem. Rev Rede Cuid Saúde [Internet]. 2013; [cited 2015 Jun 26]; 7(1):1-3. Available from: http://publicacoes.unigranrio.br/index.php/rcs/article/ view/1859/915.pdf

5. Lenza NFB, Sonobe HM, Buetto LS, Santos MG, Lima MS. O ensino do autocuidado aos pacientes estomizados e seus familiares: uma revisão integrativa. Rev Bras Prom Saúde [Internet]. 2013 Jan; [cited 2015 Jun 3]; 26(1):139-45. Available from: http://www.redalyc.org/ pdf/408/40827988019.pdf. DOI: 10.5020/18061230.2013.p139

6. Poletto D, Silva DMGV. Viver com estoma intestinal: a construção da autonomia para o cuidado. Rev Latino-Am Enferm [Internet]. 2013 Mar; [cited 2015 Aug 2]; 21(2):531-38. Available from: http://www.revistas. usp.br/rlae/article/view/75954. http://dx.doi.org/10.1590/S010411692013000200009

7. Teixeira FN, Souza NVDO, Silva PAS, Maurício VC, Costa CCP, Andrade KBS. O mundo do trabalho e as pessoas estomizadas: percepções e sentimentos. Ciênc Cuid Saúde [Internet]. 2016 Jan; [cited 2015 Aug 2]; 15(1):69-76. Available from: http://periodicos.uem.br/ojs/index. php/CiencCuidSaude/article/view/27282. http://dx.doi.org/10.4025/ cienccuidsaude.v15i1.27282

8. Muzyczka K, Kachaniuk H, Szadowska-Szlachetka Z, Charzyńska-Gula M, Kocka K, Bartoszek A, et al. Selected problems associated with the treatment and care for patients with colostomy - part 1. Contemp Onco (Pozn) [Internet]. 2013; [cited 2015 Jun 26]; 17(2):134-6. Available from: https://www.ncbi.nlm.nih.gov/pmc/articles/PMC3685365/. DOI: 10.5114/wo.2013.34615

9. Recalla S, English K, Nazarali R, Mayo S, Miller D, Gray M. Ostomy care and management: a systematic review. J Wound Ostomy Continence Nurs [Internet]. 2013 Sep; [cited 2015 Aug 2]; 40(5):489-500. Available from: http://www.nursingcenter.com/cearticle?an $=00152192$ 201309000-00009\&Journal_ID=448075\&Issue_ID=1629153

10. Mauricio VC, Oliveira NVD, Lisboa MTL. O enfermeiro e sua participação no processo de reabilitação da pessoa com estoma. Esc Anna Nery [Internet]. 2013 Jul/Aug; [cited 2017 Aug 31]; 17(3):416-22. Available from: http://www.scielo.br/scielo.php?script=sci arttext\&pid=S1414 81452013000300416\&lng=en\&nrm=iso. http://dx.doi.org/10.1590/ S1414-81452013000300003

11. Costa COM, Squarcina DF, Paula MAB. O especialista em estomaterapia In: Paula MAB, Paula PR, Cesaretti IUR. Estomaterapia em Foco e o Cuidado Especializado. São Caetano do Sul: Yendis; 2014. p. 1-12.

12. Doughty D. History of WOC(ET) Nursing Education. J Wound Ostomy Continence Nurs [Internet]. 2013 Mar/Apr; [cited 2015 Aug 3]; 40(2):127-9. Available from: http://journals.Iww.com/ jwocnonline/Citation/2013/03000/History of WOC ET Nursing Education.2.aspx. DOI: 10.1097/WON.0b013e3182850764

13. Almeida ER, Moutinho CB, Leite MTS. Prática pedagógica de enfermeiros de Saúde da Família no desenvolvimento da Educação em Saúde. Interface (Botucatu) [Internet]. 2016 Apr/Jun; [cited 2017 Jun 12]; 20(57):389-402. Available from: http://www.scielosp.org/scielo. php?script=sci_arttext\&pid=S1414-32832016000200389\&lng=en\&nrm =iso. http://dx.doi.org/10.1590/1807-57622015.0128

14. Frigotto G. O enfoque da dialética materialista na história da pesquisa educacional. In: Fazenda I, org. Metodologia da Pesquisa Educacional. Vitória: UFES; 1987.

15. Konder L. O que é dialética. São Paulo: Brasiliense; 2008. 85 p. 
16. Ministério da Saúde (BR). Conselho Nacional de Saúde. Resolução № 466, de 12 de dezembro de 2012. Diretrizes e normas regulamentadoras de pesquisas envolvendo seres humanos. Brasília (DF): Ministério da Saúde; 2012. 12 p.

17. Mendonça SN, Lameira CC, Souza NVDO, Costa CCP, Maurício VC, Silva PAS. Orientações de enfermagem e implicações para a qualidade de vida de pessoas estomizadas. Rev Enferm UFPE On Line [Internet]. 2015 Jan; [cited 2015 Jun 26]; 9(Supl.1):296-304. Available from http://www.revista.ufpe.br/revistaenfermagem/index. php/revista/article/view/5296/pdf_6990. DOI: 10.5205/reuol.5221 43270-1-RV.0901supl201506

18. Faria MGA, David HMSL, Acioli S. A educação a distância no Brasil $e$ a sua influência na saúde e na enfermagem: aspectos históricos. Cad Ciênc Saúde. 2014;3(1):87-93.

19. Menezes LCG, Guedes MVC, Oliveira RM, Oliveira SKP, Meneses LST, Castro ME. Prática de Autocuidado de estomizados: contribuições da Teoria de Orem. Rev Rene [Internet]. 2013; [cited 2015 Jun 26] 14(2):301-10. Available from: http://www.revistarene.ufc.br/revista/ index.php/revista/article/view/235

20. Cheng F, Meng AF, Yang LF, Zhang YN. The correlation between ostomy knowledge and self-care ability with psychosocial adjustment in Chinese patients with a permanent colostomy: a descriptive study. Ostomy Wound Manage [Internet]. 2013 Jul; [cited 2015 Aug 2]; 59(7):35-8. Available from: https://www.ncbi.nlm.nih.gov/ pubmed/23846005

21. Lopes APAT, Decesaro MN. Adjustments experience by persons with an ostomy: a integrative review of the literature. Ostomy Wound Manage [Internet]. 2014 Oct; [cited 2017 Aug 31]; 60(10):34-42. Available from: https://www.ncbi.nlm.nih.gov/pubmed/?term=Adjustments+experienc e+by+persons+with+an+ostomy $\% 3 \mathrm{~A}+\mathrm{a}+$ integrative+review+of+the+l iterature
22. Grant M, McCorkle R, Hornbrook MC, Wendel CS, Krouse R Development of a chronic care ostomy self-management program. J Cancer Educ [Internet]. 2013 Mar; [cited 2015 Jun 26]; 28(1):708. Available from: https://www.ncbi.nlm.nih.gov/pmc/articles/ PMC3578127/. DOI: 10.1007/s13187-012-0433-1

23. Coelho AR, Santos FS, Poggetto MTD. Stomas changing lives: Facing the illness to survive. Rev Min Enferm [Internet]. 2013 Apr/Jun; [cited 2017 Jul 20]; 17(2):268-77. Available from: http://www.reme.org.br/ artigo/detalhes/649. DOI: 10.5935/1415-2762.20130021

24. Chaves RGR, Silva CFM, Motta E, Ribeiro EDLM, Andrade YNL. Systematization of nursing care: overview of nurses. Journal of Nursing UFPE On Line [Internet]. 2016 Apr; [cited 2015 Jan 6]; 10(4):1280-5. Available from: http://www.revista.ufpe.br/revistaenfermagem/index. php/revista/article/view/8322/pdf_9977. DOI: 10.5205/reuol.846474011-1-SM.1004201615

25. Nizet J, Rigaux N. A sociologia de Erving Goffman. $1^{\text {a }}$ ed. Rio de Janeiro: Vozes; 2016. $168 p$

26. Cobb MD, Grant M, Tallman NJ, Wendel CS, Colwell J, McCorkle R, et al. Colostomy irrigation: current knowledge and practice of WOC nurses. J Wound Ostomy Continence Nurs [Internet]. 2015 Jan/Feb; [cited 2015 Aug 2]; 42(1):65-70. Available from: https://www.ncbi.nlm. nih.gov/pubmed/25325284. DOI: 10.1097/WON.0000000000000075

27. Cerezetti CRN. Psychological Instructions and reactive capacity of ostomized individuals and their relatives. Mundo Saúde [Internet].2012; [cited 2015 Jun 6]; 36(2):332-9. Available from: http://bvsms.saude.gov. $\mathrm{br} / \mathrm{bvs} /$ artigos/mundo_saude/orientacoes_piscologicas_capacidade reativa_pessoas.pdf. DOI: 10.15343/0104-78092012362332339

28. Leite GMMP, Cesaretti IUR, Paula MAB. Irrigação da colostomia: conhecimento de médicos cirurgiões. Rev Estima [Internet]. 2013 Apr [cited 2015 Aug 2]; 11(2). Available from: https://www.revistaestima. com.br/index.php/estima/article/view/83 